\title{
Uloga roditeljskih i vršnjačkih normi u objašnjenju negativnih međugrupnih stavova u adolescentnoj dobi
}

\author{
Lidija Ivandić \\ Adidas, Hrvatska
}

Ajana Löw

Odsjek za psihologiju, Filozofski fakultet Sveučilišta u Zagrebu, Hrvatska

\section{Sažetak}

Cilj istraživanja bio je ispitati ulogu roditeljskih i vršnjačkih normi u objašnjenju negativnih međugrupnih stavova u adolescentnoj dobi te provjeriti kako taj odnos ovisi o općoj podložnosti roditeljskom i vršnjačkom utjecaju. U istraživanju je sudjelovalo 457 učenika srednjih škola s područja Grada Zagreba. Ispitivani su negativni međugrupni stavovi prema etničkoj grupi Roma, a korišten je upitnik koji je sadržavao Skalu modernog rasizma, Skalu socijalne distance (samoprocjene te procjene za roditelje i vršnjake), Skalu roditeljskog i vršnjačkog utjecaja te sociodemografska pitanja. Rezultati su pokazali da sudionici u prosjeku pokazuju visoko izražen negativni stav prema Romima na mjeri socijalne distance (pristali bi ići u isti razred s Romima, ali ne i da su prijatelji, rođaci ili romantični partneri) te umjereno negativni stav na mjeri modernog rasizma. I roditeljska i vršnjačka norma značajno pridonose objašnjenju negativnog stava sudionika na mjeri socijalne distance (negativnija je norma povezana s većom distancom), pri čemu veći doprinos ima roditeljska nego vršnjačka norma. Kod modernih predrasuda doprinos je značajan samo za roditeljsku (ne i vršnjačku) normu. Pretpostavka o moderatorskom efektu opće podložnosti roditeljskom/vršnjačkom utjecaju na odnos roditeljske/vršnjačke norme i stava nije potvrđena, što je moguće objasniti metodološkim čimbenicima. Rezultati ovog istraživanja upućuju na određeni doprinos unutargrupnih normi u stvaranju i održavanju negativnih međugrupnih stavova, no potrebna su daljnja istraživanja uz metodološki strože nacrte.

Ključne riječi: roditeljske norme, vršnjačke norme, predrasude, adolescentna dob, roditeljski i vršnjački utjecaj

\section{Uvod}

Socijalna kategorizacija, jedan od ključnih procesa pri opažanju socijalne okoline, omogućuje jednostavnije snalaženje u socijalnim situacijama, a javlja se u vrlo ranoj dobi, već od tri do četiri godine (Mullen, Brown i Smith, 1992). Osim

Ajana Löw, Odsjek za psihologiju, Filozofski fakultet Sveučilišta u Zagrebu, Ivana Lučića 3, 10000 Zagreb, Hrvatska. E-pošta: ajana.low@ffzg.hr 
kategorijalnog razvrstavanja drugih ljudi, proces uključuje i samokategorizaciju (Turner, Hogg, Oakes, Reicher i Wetherell, 1987) u različite socijalne grupe. Pripadanje socijalnim grupama fundamentalna je ljudska potreba (Baumeister i Leary, 1995) jer daje doživljaj prihvaćenosti od strane drugih, osjećaj zajedništva s drugima te je važno za razvoj zdravog pojma o sebi. Unatoč svojoj važnoj funkciji procesi socijalne kategorizacije i identifikacije snažan su motivacijski faktor $u$ stvaranju negativnih međugrupnih stavova (Nesdale, 2004), negativnih vrednovanja pojedinaca na temelju grupne pripadnosti (Crandall, Eshleman i O'Brien, 2002). Iako su u novije vrijeme mnogi negativni međugrupni stavovi postali društveno neprihvatljivi, to je nažalost manje djelovalo na reduciranje takvih stavova, a više na promjenu načina njihova iskazivanja. Rezultat je toga da se sve više ispituju suptilnije manifestacije negativnih stavova, primjerice, negiranje postojanja diskriminacije ili stav da bi se manjine trebale malo više potruditi da promijene svoj nepovoljan položaj (Pearson, Dovidio i Gaertner, 2009).

Razdoblje adolescencije kritično je za razvoj identiteta mlade osobe te je obilježeno uključenošću u socijalne grupe ili klike, uz naglašenu potrebu za pripadanjem i prihvaćanjem (Lacković Grgin, 2006). Također, karakteristično je formalno mišljenje koje omogućuje bolje međugrupno razlikovanje (Prinstein i Dodge, 2008). Navedeni procesi ujedno povećavaju i osjetljivost na grupne norme. Upravo je zato važno istražiti kakve normativne poruke u pogledu stavova prema manjinskim grupama mladi dobivaju od svoje okoline, posebice one najbliže, roditelja i vršnjaka te kakvu ulogu te poruke imaju u objašnjenju negativnih međugrupnih stavova.

\section{Suvremeni pristupi međugrupnim stavovima u dječjoj $i$ adolescentnoj dobi}

Noviji pristupi međugrupnim stavovima $u$ dječjoj i adolescentnoj dobi usmjeravaju se na ulogu vlastite grupe u stvaranju negativnih stavova i procese kojima grupa regulira ponašanja svojih članova. Prema Razvojnoj teoriji socijalnog identiteta (Nesdale i Flesser, 2001) javljanje negativnih međugrupnih stavova u dječjoj i adolescentnoj dobi ovisi o stupnju unutargrupne identifikacije (koliko je vlastita grupa pojedincu važna), društvenom kontekstu (percipira li se druga grupa kao prijeteća ili neprijateljska) i tome kakav je odnos članova vlastite grupe prema članovima druge grupe. Ovisno o navedenim faktorima međugrupni stavovi mogu se kretati od jednostavne preferencije vlastite grupe do nesviđanja ili mržnje prema pripadnicima drugih grupa.

Model koji se nadovezuje na razvojnu teoriju socijalnog identiteta je Razvojni model subjektivne grupne dinamike (Abrams, Rutland, Cameron i Marques, 2003b), koji naglašava važnost normativnoga ponašanja članova grupe u objašnjenju nastanka i održavanja negativnih međugrupnih stavova. Norme propisuju pravila ponašanja u socijalnim situacijama i time postavljaju očekivanja od članova grupe. Članovi grupe koji se ne priklanjaju normama percipiraju se devijantima i ostali ih 
članovi negativno procjenjuju (čak i negativnije nego pripadnike druge grupe), što pridonosi održavanju normi. U skladu s time, utvrđeno je da djeca već od pete godine pokazuju manje sviđanja prema članovima grupe koji se ne pridržavaju grupnih normi (Abrams, Rutland i Cameron, 2003a). Općenito, poznavanje socijalnih normi pomaže u predviđanju kako i koliko je dozvoljeno iskazati predrasude i ponašati se diskriminirajuće. Primjerice, stupanj izražavanja negativnog stava prema afroamerikancima ili mentalno oboljelima znatno je niži nego prema maloljetnim delikventima ili odraslima počiniteljima kaznenih djela (Crandall i sur., 2002). Model, nadalje, postulira da porastom dobi dolazi do sve boljeg razumijevanja grupne dinamike i procesa unutar grupe, pri čemu se osobito sve jasnije uočava važnost odanosti grupi. Dok mlađa djeca sve članove grupe procjenjuju podjednako pozitivno, starija djeca diferencijalno evaluiraju ostale članove grupe na temelju njihova ponašanja, koje je "dobro" ili "loše", odnosno usklađeno ili neusklađeno s grupnim normama. Ovakvo diferencijalno evaluiranje karakteristično je upravo za razdoblje adolescencije jer se osjetljivost na grupne norme izrazito povećava nakon desete godine života (Prinstein i Dodge, 2008).

Dosadašnja su istraživanja potvrdila Razvojni model subjektivne grupne dinamike, no na sudionicima u razdoblju srednjeg djetinjstva (Abrams i sur., 2003a, 2003b; Abrams, Rutland, Pelletier i Ferrell, 2009). Primjerice, Nesdale i Lawson (2011) pokazali su da djeca te dobi imaju pozitivnije stavove prema drugoj grupi ako je norma njihove vlastite grupe prihvaćanje različitosti ( $u$ odnosu na normu odbacivanja "drugačijih"). U nedavnom su eksperimentalnom istraživanju Tomašić Humer i Črkalo Biruški (2015) potvrdile ovaj model na sudionicima rane i srednje adolescentne dobi na primjeru umjetno stvorenih (hipotetskih) ad hoc grupa. Djelovanje obitelji kao socijalne grupe čije norme djeca čvrsto usvajaju pokazala je Mićević (2005), koja je u Srbiji provela istraživanje na uzorku roditelja i djece u dobi od deset godina. Rezultati su pokazali visoko slaganje stavova roditelja i djece $u$ pogledu diskriminacije, na temelju čega autorica zaključuje da djeca te dobi u velikoj mjeri prihvaćaju stavove svoje neposredne socijalne grupe (obitelji) prema manjinskim grupama.

\section{Podložnost normama u adolescenciji}

Najjači normativni utjecaji u adolescenciji su vršnjaci i roditelji (LebedinaManzoni, Lotar i Ricijaš, 2008). Rezultati istraživanja podložnosti adolescenata roditeljskom i vršnjačkom utjecaju donekle su kontradiktorni: dok je u nekim studijama utvrđeno da su poruke od roditelja i vršnjaka uglavnom kompatibilne (npr. Collins, Maccoby, Steinberg, Hetherington i Bornstein, 2000), drugi autori navode da adolescenti dobivaju suprotne poruke o normama i pravilima ponašanja od roditelja i vršnjaka (npr. Whitaker i Miller, 2000). Pokazalo se da je utjecaj vršnjaka nedvojbeno jači onda kada je odnos između roditelja i adolescenta narušen, ako postoji moćna i homogena grupa vršnjaka čiji se stavovi jako razlikuju od roditeljskih, kada su roditeljske vrijednosti nekonzistentne te ako adolescent ima 
izrazito nisko samopoštovanje, pa se ne može oduprijeti vršnjačkom pritisku (Berndt i Savin-Williams, 1993; Conger, 1971). Utjecaj roditelja je pak jači ako se adolescent jako identificira s roditeljima (Berndt i Savin-Williams, 1993).

Općenito, pokazalo se kako vršnjaci svoj utjecaj uglavnom ostvaruju modeliranjem ponašanja, dok se roditeljski utjecaj više ostvaruje direktnim (verbalnim) izražavanjem što je prikladno, a što nije (Biddle, Bank i Marlin, 1980). Nadalje, utvrđen je moderatorski efekt vrste stavova i ponašanja na koja se utječe: vršnjaci ostvaruju svoj utjecaj na trenutna mišljenja i prolazna ponašanja, dok je roditeljski utjecaj više povezan s trajnijim društvenim vrijednostima i društvenopolitičkim stavovima (Prinstein i Dodge, 2008). Roditelji imaju veći utjecaj pri izboru zanimanja ili odlukama o raspolaganju novcem te formiranju političkih stavova i participacije, a vršnjaci su važniji u odlukama vezanim uz odijevanje, socijalne aktivnosti i zabavu (Larson, 1972). Također, u rješavanju svakodnevnih problema adolescenti se prije obraćaju bliskim prijateljima nego roditeljima (Noller, 1994), a stavovi vršnjaka imaju i veći doprinos u objašnjenju seksualnih ponašanja i stavova o seksualnosti (npr. Collins i sur., 2000). Zaključno, iako u adolescenciji odnosi s vršnjacima postaju mnogo važniji nego što su bili tijekom djetinjstva, interakcije s roditeljima i dalje su važne, a što će imati snažniji utjecaj na stavove i ponašanja adolescenata ovisi prvenstveno o kojoj temi odnosno sadržaju je riječ.

\section{Romi kao najčešći objekt negativnih (etničkih) međugrupnih stavova}

Od svih etničkih grupa Romi su najčešća meta predrasuda i u dosadašnjim su istraživanjima sudionici različite dobi pokazali najnegativnije stavove upravo prema toj etničkoj grupi. Ovakvi se nalazi dosljedno dobivaju kako na području Hrvatske (Čorkalo i Kamenov, 2003; Löw Stanić, 2014; Maričić, Kamenov i Horvat, 2012), tako i drugdje, primjerice u Mađarskoj (Todisijevič i Enyedij, 2003), Nizozemskoj (Ljujic, Vedder, Dekker i Geel, 2013), Italiji (Piumatti, Marengo, Mosso i Rabaglietti, 2015) i Rumunjskoj (Gábor i Rughinis, 2008). Prema popisu stanovništva iz 2011. godine u Hrvatskoj živi oko 17000 Roma, iako se procjenjuje da je stvaran broj i dvostruko veći (Državni zavod za statistiku, 2013). Povijesno gledajući, (negativni) stavovi prema Romima tipično su se temeljili na drugačijoj boji kože, neobičnom načinu odijevanja, načinu zarađivanja te devijantnom ponašanju poput džeparenja i krađe (Turalija, 2015). Marginalizaciji Roma pridonijelo je i često oslanjanje na socijalnu pomoć i bavljenje "skrivenom" ekonomijom. Uz to, Romi su pretežno naseljavali periferne zone grada, što je pridonijelo slabom kontaktu s većinskim stanovništvom i razvijanju specifičnog načina života. Stoga danas mladi u Zagrebu imaju slab ili nikakav kontakt s Romima, čime se dodatno povećava marginalizacija Roma (Šućur, 2000), a istraživanja pokazuju da slab kontakt dovodi do porasta negativnih stavova (Pettigrew, 1988). Bez iskustva kontakta s pripadnicima druge grupe djeca su pod većim utjecajem stavova okoline (Čorkalo Biruški i Ajduković, 2008). U tom su slučaju roditelji, vršnjaci i mediji glavni izvor za formiranje stavova. 
U Hrvatskoj je u posljednjih desetak godina provedeno nekoliko istraživanja koja su pokazala da djeca i adolescenti imaju visoku razinu socijalne distance prema Romima, višu nego prema drugim (manjinskim) grupama. Primjerice, u istraživanjima Previšića, Hrvatića i Posavec (2004) srednjoškolci su iskazali visoku socijalnu distancu prema Romima - na trećem mjestu od 13 nacionalnih manjina (viši rezultat imaju samo Srbi i Crnogorci). Tako za čak 22\% sudionika Romi nisu dobrodošli u Hrvatsku (odgovor "da ga se isključi iz države"). U istraživanju Maričić i suradnica (2012) na uzorku zagrebačke djece rane adolescentne dobi mjerena je socijalna distanca prema slijepoj djeci, djeci koja se kreću u invalidskim kolicima, pretiloj djeci te djeci romske pripadnosti. Rezultati su pokazali da sudionici iskazuju najvišu socijalnu distancu prema Romima, pri čemu $21.2 \%$ sudionika ne bi prihvatili da Romi žive u njihovoj ulici, a čak $36.7 \%$ da se druže na školskom igralištu. U eksperimentalnom istraživanju Maričić i Mihalj (2016) na uzorku djece od 10 i 11 godina autori su manipulirali opisom likova u vinjetama pri čemu su eksperimentalne grupe imale opis lika s određenim stigmatizirajućim obilježjem (romska pripadnost, korištenje invalidskih kolica ili pretilost), a opis lika u kontrolnoj grupi nije imao takvo obilježje. Veća se socijalna distanca pojavila samo u slučaju lika romske etničke pripadnosti, a slabijem prihvaćanju svih likova pridonosilo je percipiranje negativnog stava prijatelja prema likovima.

Neka su istraživanja provedena u regijama koje Romi nastanjuju duže vrijeme i gdje ih je veći udio u ukupnom stanovništvu u odnosu na ostale dijelove Hrvatske (regija Međimurje) te u regijama gdje su Romi više integrirani (Podravina, Istra). U istraživanju Hrvatića (2004) utvrđeno je da je distanca manje izražena u navedenim regijama u usporedbi s ostatkom Hrvatske, što bi išlo u prilog hipotezi kontakta, koja predviđa da će povećani kontakt smanjiti distancu. No, kao i u stranim istraživanjima (npr. Wagner, Christ, Pettigrew, Stellmacher i Wolf, 2006) odnos povećanoga međugrupnog kontakta i distance nije sasvim jednostavan te ovisi o kvaliteti kontakta. Tako su u istraživanju Šlezaka i Šakaje (2012) na uzorku sudionika rane i srednje adolescentne dobi u Međimurju usporedbom stavova u mješovitom hrvatskoromskom naselju te u naseljima bez Roma dobiveni ponešto drugačiji rezultati. Konkretno, utvrđeno je da se u mješovitom naselju javlja podjednaka socijalna distanca kao i u naseljima bez Roma, i to u oba slučaja veća nego u odraslih stanovnika tih naselja. Nalaze autori tumače lošijim školskim uspjehom te slabijim higijenskim i zdravstvenim navikama romske djece, što učenici mogu vidjeti u svakodnevnom kontaktu u školama, što posljedično održava distancu.

Kako se u razdoblju adolescencije povećava osjetljivost na grupne norme, osobito je važno istražiti kakvu ulogu normativne poruke od vršnjaka i roditelja imaju u objašnjenju negativnih međugrupnih stavova. Stoga je cilj ovog istraživanja bio utvrditi doprinos roditeljskih i vršnjačkih normi u objašnjenju negativnih međugrupnih stavova u adolescentnoj dobi te provjeriti kako taj doprinos ovisi o općoj podložnosti roditeljskom i vršnjačkom utjecaju. Konkretno, zanimao nas je afektivni aspekt (predrasuda) i ponašajni aspekt (socijalna distanca) negativnih 
međugrupnih stavova. Ovaj smo istraživački cilj željeli provjeriti na primjeru stavova prema etničkoj grupi Roma, najčešćoj meti negativnih (etničkih) stavova u Hrvatskoj. Vodeći se Razvojnom teorijom socijalnog identiteta (Nesdale i Flesser, 2001) i Razvojnim modelom subjektivne grupne dinamike (Abrams i sur., 2003b) pretpostavili smo da će roditeljske i vršnjačke norme imati značajan i relativno velik doprinos u objašnjenju predrasuda i socijalne distance kod sudionika. Pri tome smo očekivali da će sudionici čiji roditelji i vršnjaci imaju negativnije stavove prema Romima i sami imati negativnije stavove prema Romima. Također, pretpostavili smo da će opća podložnost roditeljskom, odnosno vršnjačkom utjecaju biti moderator veze između normi i stavova prema Romima. Kod sudionika koji su općenito podložniji roditeljskom/vršnjačkom utjecaju, imat će sličnije stavove roditeljima/ vršnjacima.

\section{Metoda}

\section{Sudionici}

Istraživanje je provedeno na uzorku od 457 učenika četiriju srednjih škola s područja Grada Zagreba. Dvije su srednje škole bile gimnazijskog usmjerenja (II. Gimnazija i XVI. Gimnazija), a dvije škole strukovnog usmjerenja (Škola za medicinske sestre Mlinarska i Ugostiteljsko-turističko učilište Zagreb). Ukupno je bilo 239 učenica $(52.3 \%)$ i 218 učenika (47.7\%) prosječne dobi 17 godina i 4 mjeseca $(S D=1.07)$. Kod najvećeg broja sudionika roditelji imaju srednju i višu stručnu spremu (53.6\% majki i 51.2\% očeva), potom slijedi visoka stručna sprema (44.2\% majki i $45.1 \%$ očeva) te, očekivano, najmanji je broj roditelja s osnovnoškolskim obrazovanjem (2.2\% majki i $2.4 \%$ očeva). Sudionici su u najvećoj mjeri izvještavali o prosječnom životnom standardu i to njih $55.4 \%, 40 \%$ izvještava o iznadprosječnom životnom standardu te $2.4 \%$ ispitanika navodi znatno iznadprosječan životni standard. Samo $1.8 \%$ navodi ispodprosječan i $0.4 \%$ znatno ispodprosječan životni standard.

\section{Instrumenti}

U istraživanju su korišteni sljedeći instrumenti: Skala modernog rasizma, Skala socijalne distance, Skala roditeljskog $i$ vršnjačkog utjecaja te pitanja o sociodemografskim karakteristikama (spol, dob, stupanj obrazovanja oba roditelja i životni standard).

Skala modernog rasizma (Lauri, 1999) korištena je za utvrđivanje izraženosti predrasuda prema Romima. Originalna skala ima sedam čestica i ispituje stavove prema Afroamerikancima i to na nereaktivan način kako bi se izbjeglo davanje socijalno poželjnih odgovora (McConahey, 1986). Lauri (1999) je Skalu prevela na hrvatski jezik i prilagodila za ispitivanje predrasuda prema Srbima, a u ovom je 
istraživanju korištena za istraživanje predrasuda prema Romima. Primjer je čestica "Diskriminacija Roma u Hrvatskoj ne postoji." ili "Romi postaju prezahtjevni u svojoj borbi za jednaka prava.". Pouzdanost prevedene skale tipa unutarnje konzistencije izračunate Cronbachovim alpha-koeficijentom iznosi $\alpha=.78$. Odgovori su kodirani tako da viši rezultat upućuje na veću predrasudu.

Skala socijalne distance prilagođena je za potrebe ovoga istraživanja po uzoru na Bogardusovu skalu (Bogardus, 1933). Skala se koristi za utvrđivanje stupnja preferirane distance prema pripadniku vanjske grupe, odnosno utvrđivanje koje razine bliskosti s pripadnikom vanjske grupe pojedinac odbija. $U$ ovom istraživanju Skala uključuje osam stupnjeva distance, graduiranih od manjeg prema većem stupnju ("Da mi je cura/dečko", "Da smo rođaci", "Da smo prijatelji i da se uzajamno posjećujemo i kod kuće", "Da izlazimo skupa u društvu i na ista mjesta", "Da smo prijatelji na društvenim mrežama (npr. Facebook)", "Da idemo u isti razred", "Da živimo u istoj ulici", "Da živimo u istoj državi"). Sudionici istraživanja su za svaku tvrdnju zaokruživanjem odgovora DA ili NE označavali bi li željeli biti u navedenoj situaciji ili ne. Ukupni se rezultat računao kao zbroj zaokruženih odgovora NE na Skali. Viši rezultat na skali upućuje na veću socijalnu distancu.

Za mjerenje roditeljske i vršnjačke norme korištena je ista skala, i to tako da su sudionici procjenjivali bi li njihovi roditelji/vršnjaci odobravali da se oni sami (učenici) nađu u navedenim situacijama različitog stupnja bliskosti s Romima. Tražili smo od učenika da zaokruže odgovor koji odgovara onome što bi njihovi roditelji/vršnjaci rekli na to da se učenici nađu u navedenoj situaciji. Uputa na skali procjene za roditeljsko odobravanje glasila je: "U tvrdnji 'Da smo prijatelji i da se uzajamno posjećujemo i kod kuće' ako misliš da bi tvoji roditelji odobravali da si prijatelj/ica s Romom/Romkinjom, zaokruži DA, a ako misliš da bi im smetalo, zaokruži NE.". Ista je uputa dana i za procjenu za vršnjačko odobravanje. Viši rezultat na skali upućuje na negativniju normu u pogledu stavova prema Romima, odnosno normu koja odražava veću percipiranu socijalnu distancu roditelja/vršnjaka prema Romima.

Skala socijalne distance i opisani način mjerenja roditeljske i vršnjačke norme prethodno je testiran na studentima psihologije kroz razgovor $\mathrm{u}$ fokusnoj grupi. Fokusna grupa provedena je na prigodnom uzorku od sedam sudionika, studenata završne godine psihologije. Pitanja su se odnosila na prikladnost korištenog instrumenta te su studenti komentirali kako im je bilo odgovarati na čestice upitnika. Mjerenje socijalnih normi ispitivanjem koliko bi relevantni drugi odobravali pojedine razine bliskosti ili interakcije sudionika s pripadnicima druge grupe pokazao se učinkovitim u više istraživanja. Primjerice, u istraživanju Normana, Sorrentina, Windell i Manchanda (2008) korištena je skala od sedam stupnjeva koja je mjerila razinu u kojoj bi obitelj i prijatelji odobravali određenu interakciju $\mathrm{s}$ pripadnicima druge grupe. Nadalje, nekoliko je autora upotrebljavalo kombinaciju dviju čestica "Kakav stav bi tvoji roditelji/vršnjaci željeli da zauzmeš prema pripadniku [vanjske grupe]?" uz skalu odgovora od 1 (vrlo negativan) do 7 (vrlo 
pozitivan) (npr. Mahonen, Jasinskaja-Lahti, Liebkind i Finell, 2010; Rasmussen, Damsgaard, Holstein, Poulsen i Due, 2005). Relativno sličnom su se metodom koristili Bank, Slavings i Biddle (1990), koji su tražili od sudionika da daju odgovore na određene teme onako kako misle da bi to učinili njihovi vršnjaci i roditelji. Zatim su uzimali prosječne rezultate sudionika za njihove prijatelje/roditelje za svaku pojedinu temu kako bi dobili vršnjačku/roditeljsku normu.

Skala roditeljskog $i$ vršnjačkog utjecaja (Parent and Peer Influence Scale - PPI; Werner-Wilson i Arbel, 2000) osmišljena je za mjerenje stupnja u kojemu su adolescenti i mladi odrasli pod utjecajem roditelja ili vršnjaka (relativni utjecaj roditelja naspram utjecaja vršnjaka), koja je za potrebe ovog istraživanja prvi put prevedena na hrvatski jezik i prilagođena. Skala se sastoji od 17 čestica, a procjene se donose na skali Likertova tipa 1 (u potpunosti se ne slažem) do 7 (u potpunosti se slažem). Pokriva teme moralnih vrijednosti, politička vjerovanja, izlaske, seksualnost te uporabu alkohola i drugih supstanci. Iako su u originalnoj skali pitanja kod zbrajanja rekodirana tako da viši rezultat na Skali upućuje na veću podložnost vršnjačkom utjecaju, a niži rezultat na izraženiju podložnost roditeljskom utjecaju ${ }^{1}$, za potrebe su ovog istraživanja čestice zasebno zbrajane tako da se dobiva posebno rezultat za roditeljski utjecaj te rezultat za vršnjački utjecaj. Primjer je za česticu roditeljskog utjecaja "Moji roditelji i ja imamo isti sustav vrijednost.", a za mjeru vršnjačkog utjecaja "Moji prijatelji utječu na moja uvjerenja o seksualnosti.". Faktorskom analizom odgovora metodom glavnih komponenata utvrđena su dva faktora koja ukupno objašnjavaju 51.5\% varijance rezultata na skali, a sadržajno odgovaraju roditeljskom, odnosno vršnjačkom utjecaju. Dok pouzdanost mjere vršnjačkog utjecaja iznosi $\alpha=.72$, pouzdanost mjere roditeljskog utjecaja je nešto niža $(\alpha=.68)$, ali prihvatljiva jer prelazi minimalnu razinu za istraživačke svrhe i za instrumente u razvoju od .60 (Carmines i Zeller, 1979).

\section{Postupak}

Testiranje se provodilo grupno u razredu na početku školskog sata $u$ dogovorenim terminima. Sudionici su ispunjavali upitnike tipa papir-olovka i postupak je trajao u prosjeku 15 minuta. Testiranje je bilo anonimno i dobrovoljno, a roditelji sudionika informirani su o sudjelovanju njihova djeteta $u$ istraživanju. Nitko od učenika nije odbio sudjelovanje u istraživanju. Na početku testiranja sudionici su usmeno dobili detaljnu opću uputu. Svaki je instrument u upitniku imao zasebnu uputu za rješavanje te ljestvicu $\mathrm{s}$ definiranim značenjem odgovora. Redoslijed ispunjavanja skala bio je: Skala socijalne distance za učenike, Skala socijalne distance za mjerenje roditeljske norme, Skala socijalne distance za mjerenje

\footnotetext{
${ }^{1}$ Racionala ovakva kodiranja odgovora u originalnoj skali pretpostavka je o postojanju tenzije između roditeljskog i vršnjačkog utjecaja u adolescenciji. Tenzija se javlja zbog i dalje snažnog utjecaja roditelja i želje za prihvaćanjem vršnjaka i osamostaljivanjem koja je tome suprotstavljena (Cooper i Ayers-Lopez, 1985).
} 
vršnjačke norme, Skala modernog rasizma, Skala roditeljskog i vršnjačkog utjecaja, a na kraju upitnika bila su pitanja o sociodemografskim karakteristikama.

\section{Rezultati}

U Tablici 1. prikazani su deskriptivni podaci za prediktorske varijable (roditeljska norma, vršnjačka norma, roditeljski utjecaj i vršnjački utjecaj) te kriterijske varijable (mjere negativnog stava prema Romima - predrasuda i socijalna distanca prema Romima). Vidljivo je da prosječni rezultat na Skali socijalne distance upućuje na umjereno negativan stav prema Romima, jer je mogući raspon rezultata od 0 do 8 . Na Slici 1. može se detaljnije vidjeti koliki postotak sudionika pristaje na različite stupnjeve bliskosti s Romima. Samo $24 \%$ sudionika pristalo bi na odnos "Da smo rođaci", a tek 15\% na odnos "Da mi je cura/dečko". Rezultat na Skali modernog rasizma upućuje na umjereno negativan stav prema Romima, s obzirom na mogući raspon rezultata od 1 do 35 . Roditeljska i vršnjačka norma su umjereno negativne, a prosječni su rezultati na roditeljskom i vršnjačkom utjecaju također oko srednje vrijednosti skale.

Tablica 1. Deskriptivna statistika prediktorskih i kriterijskih varijabli $(N=457)$

\begin{tabular}{lrcccc}
\hline & $M$ & SD & Min & Max & $\begin{array}{c}\text { Teoretski } \\
\text { raspon }\end{array}$ \\
\hline 1. Roditeljska norma & 3.12 & 2.22 & 0 & 8 & $0-8$ \\
2. Vršnjačka norma & 4.15 & 2.30 & 0 & 8 & $0-8$ \\
3. Roditeljski utjecaj & 22.27 & 6.95 & 6 & 42 & $6-42$ \\
4. Vršnjački utjecaj & 21.39 & 7.71 & 7 & 41 & $7-49$ \\
5. Predrasuda & 18.58 & 5.32 & 7 & 35 & $7-35$ \\
6. Socijalna distanca & 3.56 & 2.41 & 0 & 8 & $0-8$ \\
\hline
\end{tabular}

Napomena. $M$ - aritmetička sredina; $S D$ - standardna devijacija; Min - minimalna vrijednost raspona ukupnih rezultata; Max - maksimalna vrijednost raspona rezultata.

$T$-test za zavisne uzorke pokazao je da je razlika između vršnjačke i roditeljske norme za stav prema Romima statistički značajna $[t(456)=9.61, p<.01]$, pri čemu je roditeljska norma pozitivnija (odražava manju distancu). Također, $t$-test za zavisne uzorke pokazuje i statistički značajnu razliku između općega roditeljskog i općega vršnjačkog utjecaja te su sudionici općenito više pod utjecajem roditelja $[t(356)=2.42, p<.05]$. 
Slika 1. Prikaz frekvencije pojedninih odgovora na Skali socijalne distance prema Romima (samoprocjene, procjene roditeljske norme i procjene vršnjačke norme)



Za utvrđivanje povezanosti između varijabli izračunati su Pearsonovi koeficijenti korelacije prikazani u Tablici 2. U skladu s očekivanjima, rezultati na Skali socijalne distance značajno su povezani s rezultatima na Skali modernog rasizma. Nadalje, u skladu s pretpostavkama, viši je rezultat na mjeri roditeljske norme $\mathrm{u}$ pogledu negativnih stavova prema Romima povezan $\mathrm{s}$ većom socijalnom distancom sudionika prema Romima, a nešto je manja korelacija utvrđena za odnos rezultata na mjeri roditeljske norme i rezultata na Skali modernog rasizma. Također, viši rezultat na mjeri vršnjačke norme u pogledu negativnih stavova prema Romima povezan je $\mathrm{s}$ većom socijalnom distancom sudionika prema Romima, a nešto niža korelacija utvrđena je za odnos rezultata na mjeri vršnjačke norme i rezultata na Skali modernog rasizma. 
Tablica 2. Prikaz interkorelacija prediktorskih i kriterijskih varijabli $(N=457)$

\begin{tabular}{lccccccccc}
\hline & 1. & 2. & 3. & 4. & 5. & 6. & 7. & 8. & 9. \\
\hline 1. Spol & - & & & & & & & & \\
2. Obrazovanje majke & $.11^{*}$ & - & & & & & & & \\
3. Obrazovanje oca & .04 & $.55^{* *}$ & - & & & & & & \\
4. Životni standard & $.15^{* *}$ & $.30^{* *}$ & $.30^{* *}$ & - & & & & & \\
5. Roditeljski utjecaj & $.11^{* *}$ & -.01 & -.07 & -.05 & - & & & & \\
6. Vršnjački utjecaj & .08 & $.02^{* *}$ & .13 & -.04 & $.22^{* *}$ & - & & & \\
7. Roditeljska norma & .00 & -.08 & .01 & -.05 & $.12^{* *}$ & $.15^{* *}$ & - & & \\
8. Vršnjačka norma & $.15^{* *}$ & $-.09^{*}$ & -.00 & .00 & -.01 & $.14^{* *}$ & $.34^{* *}$ & - & \\
9. Socijalna distanca & $.16^{* *}$ & -.04 & .05 & $.13^{* *}$ & -.03 & $.19^{* *}$ & $.50^{* *}$ & $.43^{* *}$ & - \\
10. Predrasuda & $.18^{* *}$ & $-.16^{* *}$ & $-.13^{* *}$ & .02 & .03 & .04 & $.29^{* *}$ & $.22^{* *}$ & $.51^{* *}$ \\
\hline
\end{tabular}

${ }^{*} p<.05 ;{ }^{* *} p<.01$.

Da bismo ispitali doprinos pojedinačnih prediktora u objašnjavanju varijance stava prema Romima, provedene su dvije hijerarhijske regresijske analize, za kriterijsku varijablu socijalne distance te za kriterijsku varijablu predrasuda. Hijerarhijske regresijske analize provedene su u pet koraka. U prvom su koraku analize uvršteni prediktori demografske varijable (dob, spol, obrazovanje majke, obrazovanje oca $i$ životni standard) kao kontrolne varijable, u drugom i trećem koraku u analizu su, sukladno hipotezama, uvedene varijable normativnog utjecaja (roditeljska odnosno vršnjačka norma). Zatim je u četvrtom koraku uvrštena varijabla opće podložnosti roditeljskom utjecaju i vršnjačkom utjecaju kako bi se provjerilo predviđa li negativan stav (osim specifične norme) i generalna podložnost djelovanju roditelja i vršnjaka. U posljednjem smo koraku željeli provjeriti moderatorski efekt norme i opće podložnosti utjecaju, stoga smo uveli dvije moderatorske varijable: interakcijski odnos opće podložnosti roditeljskom utjecaju i roditeljske norme i interakcijski odnos opće podložnosti vršnjačkom utjecaju i vršnjačke norme. Moderatorska varijabla napravljena je tako da su varijable prvo centralizirane te je zatim napravljena nova varijabla koja predstavlja njihov umnožak.

U Tablici 3. možemo vidjeti da je model za predviđanje socijalne distance značajan te da prediktori u prvom koraku objašnjavaju 5.2\% varijance kriterija. Nakon uvođenja varijable roditeljska norma objašnjeno je $29.0 \%$ varijance kriterija, nakon uvođenja vršnjačke norme objašnjeno je $35.9 \%$ varijance kriterija, a nakon uvođenja opće podložnosti roditeljskom i vršnjačkom utjecaju objašnjeno je $38 \%$ ukupne varijance kriterija. U posljednjem je koraku nakon uvođenja moderatorskih varijabli objašnjeno ukupno $38.9 \%$ varijance kriterija. 
Tablica 3. Rezultati hijerarhijske regresijske analize za predviđanje socijalne distance prema Romima $(N=457)$

\begin{tabular}{|c|c|c|c|c|c|}
\hline & 1. korak & 2. korak & 3. korak & 4. korak & 5. korak \\
\hline & \multicolumn{5}{|c|}{ Standardizirani regresijski koeficijenti $(\beta)$} \\
\hline Spol & $.16^{* *}$ & $.15^{* *}$ & $.11^{* *}$ & $.11^{* * *}$ & $.12^{* * *}$ \\
\hline Dob & -.06 & -.03 & -.02 & -.01 & -.02 \\
\hline Obrazovanje majke & $-.15^{*}$ & -.08 & -.05 & -.05 & -.06 \\
\hline Obrazovanje oca & .07 & .07 & .03 & .01 & .01 \\
\hline Životni standard & $.11^{*}$ & $.14^{* * *}$ & $.13^{* *}$ & $.14^{* * *}$ & $.14^{* *}$ \\
\hline Roditeljska norma & & $.50^{* *}$ & $.41^{* *}$ & $.41^{* * *}$ & $.42^{* *}$ \\
\hline Vršnjačka norma & & & $.26^{* *}$ & $.25^{* *}$ & $.26^{* *}$ \\
\hline Roditeljski utjecaj & & & & $-.11^{* *}$ & $-.11^{* *}$ \\
\hline Vršnjački utjecaj & & & & $.12^{* *}$ & $.11^{* * *}$ \\
\hline Moderator 1 & & & & & $-.10^{*}$ \\
\hline Moderator 2 & & & & & .02 \\
\hline$R^{2}$ & .05 & .29 & .36 & .38 & .39 \\
\hline$F$ & $4.96^{* *}$ & $31.30^{* *}$ & $35.93^{* *}$ & $30.44^{* *}$ & $25.81^{* *}$ \\
\hline$\Delta R^{2}$ & & .24 & .07 & .02 & .01 \\
\hline$F_{\Delta \mathrm{R}}^{2}$ & $4.96^{* *}$ & $154.55^{* *}$ & $45.25^{* *}$ & $7.55^{* *}$ & $3.45^{*}$ \\
\hline
\end{tabular}

Napomena. $R^{2}$ - ukupan doprinos prediktora objašnjenoj varijanci; $F$ - vrijednost F-omjera; $\Delta R^{2}$ promjena u postotku objašnjene varijance kriterija; $F_{\Delta R}{ }^{2}$ - vrijednost F-omjera za statističku značajnost promjene nakon uvođenja novog bloka prediktora; Moderator 1 - Roditeljska norma x Roditeljski utjecaj; Moderator 2 - Vršnjačka norma x Vršnjački utjecaj

${ }^{*} p<.05 ;{ }^{* *} p<.01$.

Roditeljska norma najbolji je samostalni prediktor, pri čemu je negativnija norma, odnosno procjena izraženijih negativnih stavova kod roditelja povezana $\mathrm{s}$ većom socijalnom distancom sudionika prema Romima. Slijedi vršnjačka norma, koja djeluje u istom smjeru kao i roditeljska norma: negativnija norma, odnosno procjena izraženijih negativnih stavova kod vršnjaka povezana je s većom socijalnom distancom sudionika prema Romima. Opći roditeljski utjecaj također je značajan prediktor, kao i opći vršnjački utjecaj, no povezanosti su suprotnog smjera: negativniji stav prema Romima iskazuju sudionici koji su pod većim vršnjačkim, ali manjim roditeljskim općim utjecajem. U posljednjem se koraku pokazuje da je značajna interakcija roditeljske norme i općega roditeljskog utjecaja (Slika 2.), i to, neočekivano, u smjeru da što je osoba općenito više pod utjecajem roditelja, to je njezin stav manje povezan s roditeljskom normom u pogledu stava prema Romima. Interakcija vršnjačke norme i vršnjačkog utjecaja nije statistički značajna. Spol je također značajan samostalni prediktor, pri čemu djevojke iskazuju manju socijalnu distancu prema Romima u odnosu na mladiće. Također, može se primijetiti da je obrazovanje majke značajan samostalni prediktor u prvom koraku analize, a gubi na značajnosti u drugom koraku uvođenjem varijable roditeljska norma. To bi moglo upućivati da se efekt obrazovanja majke ostvaruje putem norme koju majke postavljaju i tako se odražava na stavove sudionika. 
Slika 2. Prikaz moderatorskoga efekta opće podložnosti roditeljskom utjecaju na odnos roditeljske norme i socijalne distance sudionika prema Romima

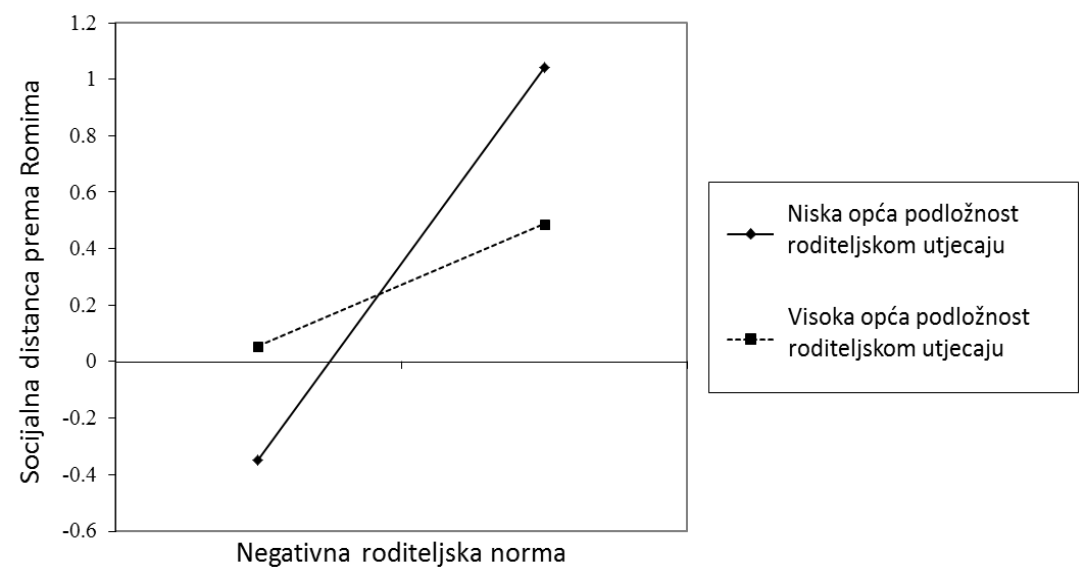

Tablica 4. Rezultati hijerarhijske regresijske analize za predviđanje predrasude prema Romima $(N=457)$

\begin{tabular}{|c|c|c|c|c|c|}
\hline & 1. korak & 2. korak & 3. korak & 4. korak & 5. korak \\
\hline & \multicolumn{5}{|c|}{ Standardizirani regresijski koeficijenti $(\beta)$} \\
\hline Spol & $.19^{* *}$ & $.19^{* *}$ & $.17^{* *}$ & $.18^{* *}$ & $.18^{* * *}$ \\
\hline Dob & .02 & .03 & .04 & .04 & .03 \\
\hline Obrazovanje majke & $-.18^{* *}$ & $-.14^{* *}$ & -.13 & $-.13^{*}$ & $-.14^{*}$ \\
\hline Obrazovanje oca & -.05 & -.08 & -.08 & -.08 & -.08 \\
\hline Životni standard & -.07 & .08 & .08 & .08 & .08 \\
\hline Roditeljska norma & & $.28^{* * *}$ & $.25^{* *}$ & $.25^{* *}$ & $.26^{* *}$ \\
\hline Vršnjačka norma & & & $.10^{*}$ & $.10^{*}$ & .09 \\
\hline Roditeljski utjecaj & & & & -.03 & -.03 \\
\hline Vršnjački utjecaj & & & & .01 & .01 \\
\hline Moderator 1 & & & & & -.03 \\
\hline Moderator 2 & & & & & -.03 \\
\hline$R^{2}$ & .08 & .16 & .16 & .16 & .17 \\
\hline$F$ & $7.51^{* *}$ & $13.79^{* *}$ & $12.57^{* *}$ & $9.78^{* *}$ & $8.07^{* *}$ \\
\hline$\Delta R^{2}$ & & .08 & .01 & .00 & .00 \\
\hline$F_{\Delta \mathrm{R}^{2}}$ & $7.51^{* *}$ & $41.83^{* *}$ & $4.58^{* *}$ & .15 & .48 \\
\hline
\end{tabular}

Napomena. $R^{2}$ - ukupan doprinos prediktora objašnjenoj varijanci; $F$ - vrijednost F-omjera; $\Delta R^{2}-$ promjena u postotku objašnjene varijance kriterija; $F_{\Delta R}{ }^{2}$ - vrijednost $\mathrm{F}$-omjera za statističku značajnost promjene nakon uvođenja novog bloka prediktora; Moderator 1 - Roditeljska norma x Roditeljski utjecaj; Moderator 2 - Vršnjačka norma x Vršnjački utjecaj

${ }^{*} p<.05 ;{ }^{* *} p<.01$. 
Rezultati za drugu kriterijsku varijablu (predrasudu) ponešto su drugačiji. U Tablici 4. možemo vidjeti da su samo promjene u prva tri koraka modela značajna. U prvom je koraku objašnjeno 7.7\% varijance kriterija, nakon uvođenja varijable roditeljska norma objašnjeno je $15.5 \%$ varijance kriterija te je nakon uvođenja varijable vršnjačka norma objašnjeno ukupno $16.4 \%$ varijance kriterija. Promjene u daljnjim koracima ove hijerarhijske regresijske analize nisu značajne. U zadnjem su koraku analize značajna samo tri prediktora: roditeljska norma, spol te obrazovanje majke. Negativnija roditeljska norma i muški spol su povezani s većom predrasudom prema Romima, dok je više obrazovanje majke povezano s manjom predrasudom prema Romima.

\section{Rasprava}

Cilj je ovog istraživanja bio utvrditi doprinos roditeljskih i vršnjačkih normi u objašnjenju negativnih međugrupnih stavova u adolescentnoj dobi te provjeriti kako taj doprinos ovisi o općoj podložnosti roditeljskom i vršnjačkom utjecaju. Ovaj smo istraživački cilj željeli provjeriti na primjeru stavova prema etničkoj grupi Roma, najčešćoj meti negativnih (etničkih) stavova u Hrvatskoj. Rezultati općenito pokazuju umjereno negativan stav sudionika prema Romima na obje kriterijske varijable. Međutim, pri interpretaciji rezultata treba uzeti u obzir da niži rezultati (a čak i rezultati oko aritmetičke sredine) zapravo upućuju na relativno visoku razinu distance: rezultat 3 znači da bi sudionici pristali na suživot $u$ istoj državi, istoj ulici ili da idu u isti razred, no ne bi pristali na veći stupanj bliskosti. Mnogi sudionici ne bi htjeli biti čak niti prijatelji na društvenim mrežama, a intimnije odnose poput prijateljstava ili romantične veze prihvatilo bi samo oko $20 \%$ sudionika.

Vodeći se Razvojnom teorijom socijalnog identiteta (Nesdale i Flesser, 2001) i Razvojnim modelom subjektivne grupne dinamike (Abrams i sur., 2003b), pretpostavili smo da će roditeljske i vršnjačke norme imati značajan i relativno velik doprinos u objašnjenju predrasuda i socijalne distance kod sudionika. Pri tome smo očekivali da će sudionici čiji roditelji i vršnjaci imaju negativnije stavove prema Romima i sami imati negativnije stavove prema Romima. Ukupnim modelima objašnjen je supstancijalan postotak varijance kriterija (38.9\% za socijalnu distancu i $16.4 \%$ za predrasudu). U skladu je s hipotezama negativnija roditeljska i vršnjačka norma povezana s većom socijalnom distancom i predrasudom sudionika prema Romima. Drugim riječima, adolescenti koji percipiraju da njihovi roditelji i vršnjaci imaju negativniji stav prema Romima skloni su i sami iskazivati negativniji stav prema toj marginaliziranoj grupi. Utvrđeni rezultati upućuju na to da bi znakovi koji dolaze iz okoline o normama u pogledu stavova prema marginaliziranim društvenim skupinama, mogli biti snažan čimbenik koji determinira međugrupne stavove adolescenata. 
Dobiveni su nalazi u skladu s novijim pristupima međugrupnim stavovima $\mathrm{u}$ dječjoj i adolescentnoj dobi, koji se usmjeravaju na ulogu vlastite grupe (npr. vršnjačke, obiteljske) u stvaranju predrasuda, odnosno procese kojima grupa regulira ponašanja svojih članova. Razvojni model subjektivne grupne dinamike (Abrams i sur., 2003b) naglašava važnost normativnog ponašanja članova grupe u objašnjenju nastanka i održavanja negativnih stavova te također ističe da s dobi raste različito evaluiranje članova vlastite grupe ovisno o tome koliko se pridržavaju grupnih normi. Članovi grupe koji se ne priklanjaju normama percipiraju se devijantima, što pomaže u održavanju normi. Mlađa djeca sve članove grupe procjenjuju slično, dok adolescenti različito evaluiraju članove grupe na temelju ponašanja koje je "dobro" ili "loše", odnosno usklađeno ili neusklađeno s normama. Diferencijalno evaluiranje karakteristično je upravo za razdoblje adolescencije jer se osjetljivost na grupne norme izrazito povećava nakon desete godine (Prinstein i Dodge, 2008). Stoga ne iznenađuje da se i kod sudionika našeg istraživanja pokazala značajna (i relativno visoka) povezanost grupnih normi i predrasuda prema Romima. Grupne norme koje smo ispitivali su norme roditelja (obitelji) i vršnjaka, osoba koje sudionici viđaju svaki dan i s kojima su u intenzivnoj i vremenski najduljoj interakciji, stoga ne čudi da te grupe predstavljaju najveće utjecaje na stavove.

U dosadašnjim je istraživanjima Razvojni model subjektivne grupne dinamike potvrđen za djecu u razdoblju srednjeg djetinjstva, dok je, koliko nam je poznato, jedino istraživanje na sudionicima u adolescentnoj dobi nedavno istraživanje koje su provele Tomašić Humer i Čorkalo Biruški (2015). Međutim, spomenuto je istraživanje provedeno eksperimentalnom paradigmom na ad hoc (a ne prirodnim grupama) te su sudionici bili rane i srednje adolescentne dobi, dok su naši sudionici u kasnijoj adolescentnoj dobi te je riječ o prirodnim (već postojećim) etničkim grupama. Stoga nalazi našeg istraživanja predstavljaju nov doprinos području i upućuju na to da bi Razvojni model subjektivne grupne dinamike mogao biti primjenjiv i na kasnu adolescentnu dob. Međutim, potrebno je napomenuti da je riječ o korelacijskom istraživanju te da je moguće pretpostaviti i drugi smjer djelovanja varijabli - činjenica, naime, da adolescent ima negativan stav utječe na to da procjenjuje stav svoje okoline negativnijim. Također, moguće je i da neka treća varijabla utječe i na njih i na okolinu (primjerice, poruke iz medija).

Rezultati su, nadalje, pokazali da je roditeljska norma vezana uz negativne stavove prema Romima snažnija od vršnjačke norme. Roditeljskom je normom objašnjen veći postotak varijance socijalne distance nego vršnjačkom normom, a za predrasudu vršnjačka norma nije uopće prediktivna. Dobiveni nalazi upućuju na to da bi predrasude u adolescentnoj dobi, barem one koje se tiču drugih etničkih grupa, mogle biti pod većim utjecajem stava roditelja nego vršnjaka. Iako je u adolescentnoj dobi izrazito važan osjećaj prihvaćenosti od vršnjačke grupe, važni su i stavovi i vrijednosti primarnih izvora socijalizacije, poput obitelj i susjedstva (Lebedina Manzoni i sur., 2008). Hoće li prevladati utjecaj vršnjaka ili obitelji ovisi o nizu čimbenika. Tako se pokazalo da razlika u stupnju podložnosti normama roditelja u 
odnosu na vršnjake ovisi o različitim mehanizmima na koje se utjecaj normi prenosi: dok vršnjaci svoj utjecaj uglavnom ostvaruju modeliranjem ponašanja, roditeljski se utjecaj više ostvaruje direktnim izražavanjem što je prikladno, a što nije (Biddle i sur., 1980). Stoga je moguće da su stavovi adolescenata u našem istraživanju više povezani s roditeljskom nego $s$ vršnjačkom normom zbog toga što dvije norme djeluju različitim putevima. Roditeljska norma vjerojatnije ostvaruje svoj utjecaj kroz izravno prenošenje stava o manjinama, pa tako i Romima. S druge strane, norma vršnjaka možda se više prenosi kroz konkretno ponašanje, odnosno diskriminaciju Roma, koju adolescenti, zbog relativno slabog kontakta s Romima u svakodnevnom životu, nemaju prilike često vidjeti. Također, utvrđena bi razlika mogla biti i posljedica toga što snaga utjecaja normi ovisi o temi/sadržaju. Naime, dok vršnjaci ostvaruju svoj utjecaj ponajprije na trenutna mišljenja i prolazna ponašanja, roditeljski je utjecaj više povezan s trajnijim društvenim vrijednostima i društvenopolitičkim stavovima (Prinstein i Dodge, 2008). Roditelji imaju veći utjecaj pri izboru zanimanja ili odlukama o raspolaganju novcem te formiranju političkih stavova i participacije, dok su vršnjaci važniji u odlukama vezanim uz odijevanje, socijalne aktivnosti, seksualnost i zabavu (Collins i sur., 2000; Larson, 1972). Moguće da su vršnjačke norme kod naših sudionika možda više orijentirane na neke druge teme kojima se adolescenti bave, primjerice, škola i ocjene, izlasci, odnosi s prijateljima, roditeljima te braćom i sestrama, dok se stavova prema marginaliziranim grupama, poput Roma, ne dotiču u razgovorima s vršnjacima.

Drugo je istraživačko pitanje bilo provjeriti moderatorski utjecaj opće podložnosti roditeljskom utjecaju/vršnjačkom utjecaju na odnos roditeljskih/ vršnjačkih normi i predrasuda. Pretpostavili smo da će sudionici koji su općenito podložniji roditeljskom/vršnjačkom utjecaju, imati sličnije stavove roditeljima/ vršnjacima $u$ pogledu predrasuda prema Romima. Rezultati nisu potvrdili postavljenu hipotezu. Značajan moderatorski efekt opće podložnosti vršnjačkom utjecaju nije utvrđen, a moderatorski efekt općega roditeljskog utjecaja, iako značajan, malog je reda veličine te negativnog predznaka, dakle, u suprotnom smjeru od očekivanog. Negativan predznak interakcijskog efekta znači da što je vrijednost jednog prediktora iz interakcijskog odnosa pozitivnija, to je odnos između drugog prediktora i kriterija negativniji. U našem bi slučaju to značilo da što je adolescent manje pod općim utjecajem roditelja, to je izraženija povezanost njegova stava $\mathrm{s}$ roditeljskom normom u vezi stava prema Romima, odnosno to je njegov stav sličniji roditeljskoj normi u vezi stava prema Romima. Iako je nalaz na prvi pogled vrlo neobičan, potrebno je naglasiti da je već na razini samostalnih prediktora povezanost predrasuda s općim roditeljskim utjecajem suprotnog (i neočekivanog) smjera: više predrasude prema Romima iskazuju sudionici koji su pod manjim roditeljskim općim utjecajem. Negativni bismo predznak mogli interpretirati kao odraz toga da su adolescenti koji su pod slabijim roditeljskim nadzorom općenito (na što može upućivati rezultat na mjeri općega roditeljskog utjecaja), ujedno skloniji agresivnijim tendencijama prema vršnjacima i drugim rizičnim ponašanjima pa tako i socijalnoj distanci prema marginaliziranim manjinama, koje su upravo česte žrtve nasilnih 
ponašanja. Istraživanja u etnički podijeljenim zajednicama u kojima je izraženo međuetničko nasilje među djecom i mladima roditeljski nadzor može biti važna varijabla za objašnjenje međuetničke napetosti i sukoba među grupama. Tako su, primjerice, Cummings i suradnici (2010) u Sjevernoj Irskoj utvrdili da je sa slabijim roditeljskim nadzorom nad djecom povezana veća pojava političkog nasilja u zajednici i diskriminacije. Također, studije su općenito pokazale da je slabije otvaranje i dijeljenje informacija s roditeljima te manja kohezivnost i podrška unutar obitelji povezana $\mathrm{s}$ većim stupnjem agresivnosti i smanjenim prosocijalnim ponašanjem (npr. Keresteš, 1999). Međutim, istraživanja su korelacijskog karaktera, stoga nije sasvim jasno koji je mehanizam u podlozi te povezanosti i je li moguće da je neka treća varijabla, primjerice, veća sklonost međuetničkim predrasudama kod roditelja koji pokazuju slabiji nadzor, uzrok te povezanosti.

U navedenoj bi pretpostavci moglo ležati i objašnjenje negativnog predznaka interakcije. Naime, mjera roditeljskog utjecaja koju smo koristili sadržajno je prilično udaljena od toga što čini sadržaj norme u vezi s predrasudama prema različitim društvenim grupama, konkretno u našem slučaju, Romima. U skali podložnosti roditeljskom utjecaju čestice su uglavnom vezane uz sadržaje poput rizičnih ponašanja (ovisnosti i rizična seksualna ponašanja), izlasci, odabir prijatelja i sl., što je tematski vrlo udaljeno od predrasuda prema manjinskim grupama, a zapravo je više povezano sa sadržajima koji čine roditeljsko uključivanje, nadzor, dijeljenje informacija i podršku. Stoga je moguće da je veća sklonost međuetničkim predrasudama kod roditelja koji pokazuju slabiji utjecaj na adolescente uzrok veće povezanosti negativnog stava sudionika koji su pod slabijim utjecajem roditelja i negativne roditeljske norme.

Općenito, važno je reći i da su rezultati pokazali općenito negativniji stav sudionika na skali socijalne distance nego na skali modernih predrasuda, a prediktivni model objašnjava znatno veći postotak varijance kriterija socijalne distance (38.9\%), nego predrasuda (16.4\%). S jedne je strane moguće da je skala socijalne distance, samim svojim sadržajem (ispitivanje ponašajnog aspekta predrasuda), a i time što je u način odgovaranja uključen prisilan izbor, što smanjuje socijalno poželjno odgovaranje, jednostavno točniji i prikladniji pokazatelj stvarne razine negativnog stava. U prilog tome govore istraživanja u kojima je utvrđeno da su skale modernih predrasuda, iako bi trebale biti najbolja mjera predrasuda $u$ današnje vrijeme, ipak prilično osjetljive na socijalnu poželjnost (npr. Fazio, Jackson, Dunton i Williams, 1995). Nadalje, fizičko distanciranje od vanjske grupe može se javiti i bez izražavanja predrasuda, u obliku prostornog odvajanja među grupama u svakodnevnom životu (Tredoux i Dixon, 2009), što ponovno govori u prilog tome da je socijalna distanca "jača" mjera negativnoga stava. $S$ druge je strane moguće da je dobiveni rezultat djelomično i posljedica metodološkog faktora, točnije načina ispitivanja normi. Naime, sudionici su na skali socijalne distance najprije procjenjivali na koji bi stupanj bliskosti od navedenih situacija pristali, a zatim su trebali na istoj skali procijeniti što misle koje bi situacije odobravali njihovi roditelji, 
odnosno vršnjaci. Dakle, ista skala i isti način odgovaranja korišten je i za samoprocjenu i za procjenu roditeljske i vršnjačke norme, što je moglo dovesti do toga da je, zbog faktora metode, povezanost rezultata viša u slučaju kada je stav mjeren skalom socijalne distance nego kada je mjeren skalom modernog rasizma.

Ovo je istraživanje proširilo dosadašnje spoznaje vezane uz odnos unutargrupnih normi i međugrupnih stavova kod adolescenata. Koliko nam je poznato, istraživanja koja su provjeravala navedeni odnos na prirodnim socijalnim grupama dosad u Hrvatskoj još nisu provedena, stoga nalazi mogu dati izvorni doprinos području. U pogledu praktične primjene ovo istraživanje podsjeća nas na ključnu ulogu socijalne okoline u formiranju (negativnih) stavova, ali upućuje i na velik potencijal koji upravo zbog toga ista okolina ima u mogućnosti promjene stavova. Također, ako djeca nemaju priliku dovesti u pitanje stavove okoline u kojoj odrastaju, najvjerojatnije će ih prihvatiti. Zato je vrlo važno da mladi imaju priliku propitkivati svoje stavove, posebice prema marginaliziranim grupama. U tome važnu ulogu može imati obrazovanje - prvenstveno škola kao ključan socijalizacijski agens djece i mladih. Različiti programi građanskog odgoja i obrazovanja mogu uvelike pridonijeti smanjenju predrasuda. Različite strane studije pokazale su da i obrazovne intervencije manjeg opsega mogu biti učinkovite $u$ povećanju međugrupne tolerancije (npr. Pettijohn i Walzer, 2008). Drugi mehanizam za povećanje tolerancije je međugrupni kontakt koji ako je adekvatno proveden, dovodi do smanjenja negativnih međugrupnih stavova, što istraživanja konzistentno pokazuju (npr. Brown, Eller, Leeds i Stace, 2007). Naše je istraživanje provedeno u Zagrebu, gdje mladi imaju slab ili nikakav kontakt s Romima, a ako i imaju kontakt, interakcije su većinom neutralne ili negativne (primjerice, susret s Romima koji prose na ulici, a povremeno su uključeni i u sitne krađe ili verbalne sukobe). Takav općeniti manjak pozitivnog i kvalitetnog kontakta vjerojatno pridonosi stvaranju, ali i održavanju socijalne distance prema Romima.

Povezano s time, u svrhu poboljšanja metodologije istraživanja, bilo bi dobro proširiti uzorak i na adolescente iz drugih gradova u Hrvatskoj. Posebno bi bilo zanimljivo uključiti manje gradove u kojima postoje romske zajednice te u kojima škole redovno polaze i adolescenti iz romske manjine. Nadalje, mjera koja je u ovom istraživanju korištena za ispitivanje podložnosti roditeljskom/vršnjačkom utjecaju pokriva moralne vrijednosti, politička vjerovanja, izlaske, seksualnost te uporabu alkohola i drugih supstanci. Stoga je moguće da rezultat ne predstavlja dobro utjecaj koji se odnosi na predrasude prema različitim društvenim grupama. Također, u ovom je istraživanju korištena metoda prisilnog izbora, koja, unatoč značajnim prednostima, ima i određene nedostatke (Nederhof, 1985). Kada je riječ o skali socijalne distance, na rezultat može utjecati što za različite sudionike pojedini stupnjevi skale nisu jednako podložni utjecaju socijalne poželjnosti, a također rezultati mogu imati veći broj nedostajućih vrijednosti jer se sudionici ponekad ne mogu odlučiti na odgovor. Nadalje, skali socijalne distance prigovara se da poredak stupnjeva nije univerzalno primjenjiv na sve ljude (nekima je, primjerice, da živimo 
$\mathrm{u}$ istoj ulici bliži stupanj nego polaženje istog razreda), a to može, osim o individualnim faktorima, ovisiti i o društvenim i kulturnim faktorima (primjerice, promjena u tome koliko je blizak odnos na društvenim mrežama). Konačno, problematično je i koliko su stupnjevi na skali ekvidistantni (Krosnick, Judd i Wittenbrink, 2005). Jedan je od nedostataka ovog istraživanja i što su roditelji prikazani jedinstveno - moguća je posljedica ovakva načina postavljanja pitanja što sudionik možda pri odgovoru bira roditelja koji mu je sličniji. Činjenica da to nismo kontrolirali u istraživanju također predstavlja metodološko ograničenje jer su istraživanja pokazala da majke općenito u nešto većoj mjeri imaju socijalizacijski utjecaj na političke i društvene stavove adolescenata, i kod mladića i kod djevojaka (npr. Acock i Bengtson, 1978). Nadalje, utvrđeno je i da se, ovisno o vrsti društvenih stavova, konkretnije objektu predrasuda, javlja diferencijalni utjecaj spola roditelja: majke imaju veći utjecaj na rasne i etničke predrasude, predrasude prema pretilima i oboljelima od AIDS-a, a očevi na rodne predrasude i predrasude prema homoseksualcima (npr. O'Bryan, Fishbein i Ritchey, 2004). Također, ograničenje je istraživanja i što su u skali podložnosti vršnjačkom/roditeljskom utjecaju čestice formulirane korištenjem termina "moji prijatelji". Iako su pojmovi "prijatelj" i "vršnjak" relativno bliski te se vršnjački utjecaj najčešće očituje u utjecaju onih vršnjaka koji su adolescentu (bliski) prijatelji, ta dva pojma ne mogu se izjednačavati, odnosno potreban je veći oprez pri donošenju zaključaka. Na kraju, kako je ranije spomenuto, korelacijski nacrt ne omogućuje zaključivanje o uzročno posljedičnim vezama, stoga bi istraživanje valjalo provesti korištenjem eksperimentalnoga ili longitudinalnoga korelacijskog nacrta.

Zaključno, ovo je istraživanje pokazalo kako negativne roditeljske i vršnjačke norme značajno pridonose objašnjenju negativnog stava sudionika prema Romima, pri čemu veći doprinos ima roditeljska nego vršnjačka norma. Pretpostavka o moderatorskom efektu opće podložnosti roditeljskom/vršnjačkom utjecaju na odnos normi i stava nije potvrđena. Iako je, neočekivano, dobivena viša povezanost negativnog stava sudionika koji su pod slabijim utjecajem roditelja i negativne roditeljske norme, takav bi se nalaz mogao objasniti metodološkim čimbenicima i hipotezom o većoj sklonosti međuetničkim predrasudama kod roditelja koji pokazuju slabiji utjecaj na adolescente. S obzirom na manjak istraživanja odnosa među ispitivanim varijablama na prirodnim socijalnim grupama u Hrvatskoj, nalazi ovog istraživanja mogu dati izvorni doprinos području; rezultati općenito upućuju na potencijalni značaj unutargrupnih normi u stvaranju i održavanju negativnih međugrupnih stavova, no potrebna su daljnja istraživanja uz metodološka poboljšanja. 


\section{Literatura}

Abrams, D., Rutland, A. i Cameron, L. (2003a). The development of subjective group dynamics: Children's judgments of normative and deviant in-group and outgroup individuals. Child Development, 74(6), 1840-1856.

Abrams, D., Rutland, A., Cameron, L. i Marques, J.M. (2003b). The development of subjective group dynamics: When ingroup bias gets specific. British Journal of Developmental Psychology, 21(2), 155-176.

Abrams, D., Rutland, A., Pelletier, J. i Ferrell, J. (2009). Children's group nous: Understanding and applying peer exclusion within and between groups. Child Development, 80, 224-243.

Acock, A.C. i Bengtson, V.L. (1978). On the relative influence of mothers and fathers: A covariance analysis of political and religious socialization. Journal of Marriage and the Family, 40(3), 519-530

Bank, B-J., Slavings, R.L. i Biddle, B.J. (1990). Effects of peer, faculty, and parental influences on students' persistence. Sociology of Education, 63(3), 208-225.

Baumeister, R.F. i Leary, M.R. (1995). The need to belong: Desire for interpersonal attachment as a fundamental human motivation. Psychological Bulletin, 117, 497-529.

Berndt, T.J. i Savin-Williams, R.C. (1993). Peer relations and friendships. U: P.H. Tolan i B.J. Cohler (Ur.), Handbook of clinical research and practice with adolescents (str. 203219). New York: John Wiley \& Sons.

Biddle, B.J., Bank, B.J. i Marlin, M.M. (1980). Parental and peer influence on adolescents. Social Forces, 58(4), 1057-1079.

Bogardus, E.S. (1933). A social distance scale. Sociology and Social Research, 17, 265-271.

Brown, R., Eller, A., Leeds, S. i Stace, K. (2007). Intergroup contact and intergroup attitudes: A longitudinal study. European Journal of Social Psychology, 37, 692-703.

Carmines, E.G. i Zeller, R.A. (1979). Reliability and validity of assessment. Beverly Hills, CA: Sage.

Collins, W.A., Maccoby, E.E., Steinberg, L., Hetherington, E.M. i Bornstein, M.H. (2000). Contemporary research on parenting: The case for nature and nurture. American Psychologist, 55(2), 218-232.

Conger, J.J. (1971). A world they never knew: The family and social change. Daedalus, 100, 1128-1142.

Cooper, C.R. i Ayers-Lopez, S. (1985). Family and peer systems in early adolescents: New models of the role of relationships in development. Journal of Early Adolescence, 5, 921.

Crandall, C.S., Eshleman, A. i O'Brien, L. (2002). Social norms and the expression and suppression of prejudice: The struggle for internalization. Journal of Personality and Social Psychology, 82, 359-378. 
Cummings, E.M., Merrilees, C.E., Schermerhorn, A.C., Goeke-Morey, M.C., Shirlow, P. i Cairns, E. (2010). Testing a social ecological model for relations between political violence and child adjustment in Northern Ireland. Development and Psychopathology, 22(2), 405-418.

Čorkalo Biruški, D. i Ajduković, D. (2008). Stavovi učenika, roditelja i nastavnika prema školovanju: Što se promijenilo tijekom šest godina u Vukovaru? Migracijske i etničke teme, 24, 189-216.

Čorkalo, D. i Kamenov, Ž. (2003). National identitiy and social distance. Review of Psychology, 10(2), 85-94.

Državni zavod za statistiku (2013). Popis stanovništva, kućanstava i stanova 2011. Stanovništvo prema državljanstvu, narodnosti, vjeri i materinskom jeziku. Statističko izvješće. Preuzeto s http://www.dzs.hr/

Fazio, R.H., Jackson, J.R., Dunton, B.C. i Williams, C.J. (1995). Variability in automatic activation as an unobtrusive measure of racial attitudes: A bona fide pipeline? Journal of Personality and Social Psychology, 69(6), 1013-1027.

Gábor, F. i Rughinis, C. (2008). Come closer. Inclusion and exclusion of Roma in presentday Romanian society. Bucharest: Human Dynamics.

Hrvatić, N. (2004). Romi u Hrvatskoj: Od migracija do interkulturalnih odnosa. Migracijske $i$ etničke teme, 20(4), 367-385.

Keresteš, G. (1999). Agresivno i prosocijalno ponašanje školske djece u kontekstu ratnih zbivanja: Provjera posredujućeg utjecaja roditeljskog ponašanja. (Neobjavljena doktorska disertacija). Odsjek za psihologiju Filozofskog fakulteta u Zagrebu, Zagreb.

Krosnick, J.A, Judd, C.M. i Wittenbrink, B. (2005). Attitude measurement. U: D. Albarracin, B.T. Johnson i M.P. Zanna (Ur.), Handbook of attitudes and attitude change (str. 2176). Mahwah, NJ: Erlbaum.

Lacković-Grgin, K. (2006). Psihologija adolescencije. Jastrebarsko: Naklada Slap.

Larson, L.E. (1972). Adolescence: The situation hypothesis revisited. Journal of Marriage and Family, 34(1), 67-74.

Lauri, A. (1999). Provjera Pettigrewovih postavki o izraženosti "krajnje atribucijske pogreške". (Neobjavljeni diplomski rad). Sveučilište u Zagrebu, Filozofski fakultet, Zagreb.

Lebedina-Manzoni, M., Lotar, M. i Ricijaš, N. (2008). Podložnost vršnjačkom pritisku i samopoštovanje kod studenata. Hrvatska revija za rehabilitacijska istraživanja, 1, 77 92.

Löw Stanić, A. (2014). Predrasuda i prikazivanje Roma u medijima: Može li jedna televizijska emisija povećati međugrupnu toleranciju? Društvena istraživanja, 23(2), 303-325.

Ljujic, V., Vedder, P., Dekker, H. i Geel, M. (2013). Romaphobia among Serbian and Dutch adolescents: The role of perceived threat, nationalistic feelings, and integrative orientations. International Journal of Psychology, 48(3), 352-362.

Mahonen, T., Jasinskaja-Lahti, I., Liebkind, K. i Finell, E. (2011). Perceived importance of contact revisited. Group Processes \& Intergroup Relations, 14(1), 19-30. 
Maričić, J., Kamenov, Ž. i Horvat, K. (2012). Predrasude u dječjoj dobi: Provjera dviju skala socijalne distance. Društvena istraživanja, 21(1), 137-158.

Maričić, J. i Mihalj, M. (2016). The role of contact and perceived attitudes of surroundings in children's acceptance of "different" peers. Psihologija, 49(1), 1-35.

McConahay, J.B. (1986). Modern racism, ambivalence and the Modern Racism Scale. U: J.F. Dovidio i S.L. Gaertner (Ur.), Prejudice, discrimination, and racism (str. 99-125). Orlando, Florida: Academic Press.

Mićević, J. (2005). Razlike u stavovima prema marginalnim grupama između roditelja i njihove djece. Psihologija, 38(2), 1-13.

Mullen, B., Brown, R. i Smith C. (1992). Ingroup bias as a function of salience, relevance, and status: An integration. European Journal of Social Psychology, 22, 103-22.

Nederhof, A.J. (1985). Methods of coping with social desirability bias: A review. European Journal of Social Psychology, 15, 263-280.

Nesdale, D. (2004). Social identity processes and childrens ethnic prejudice. U: M. Bennett i F. Sani (Ur.), The development of the social self(str. 219-246). East Sussex: Psychology Press.

Nesdale, D. i Flesser, D. (2001). Social identity and the development of children's group attitudes. Child Development, 72(2), 506-517.

Nesdale, D. i Lawson, M. (2011). Social groups and children's intergroup attitudes: Can school norms moderate the effects of social group norms?. Child Development, 82(5), $1-13$.

Noller, P. (1994). Relationships with parents in adolescence: Process and outcome. U: R. Montemayor, G.R. Adams i T.P. Gullotta (Ur.), Personal relationships during adolescence: Advances in adolescent development (str. 37-77). Thousand Oaks, CA: Sage.

Norman, R.M, Sorrentino R.M., Windell D. i Manchanda, R. (2008). The role of perceived norms in the stigmatization of mental illness. Social Psychiatry \& Psychiatric Epidemiology, 43(11), 851-859.

O'Bryan, M., Fishbein, H.D. i Ritchey, P.N. (2004). Intergenerational transmission of prejudice, sex role stereotyping, and intolerance. Adolescence, 39(155), 407-426.

Pearson, A.R., Dovidio, J.F. i Gaertner, S.L. (2009). The nature of contemporary prejudice: Insights from aversive racism. Social and Personality Psychology Compass, 3, 314-338.

Pettigrew, T.F. (1988). Intergroup contact theory. Annual Review of Psychology, 49, 65-85.

Pettijohn, T.F. i Walzer, A.S. (2008). Reducing racism, sexism and homophobia in college students by colmpleting a psychology of prejudice course. College Student Journal, 42(2), 459-468.

Piumatti, G., Marengo, D., Mosso, C. i Rabaglietti, E. (2015). Readiness for aggression and ethnic prejudice among Italian adolescents. Cognition, Brain, Behavior, 19(1), 1-16.

Previšić, V., Hrvatić N. i Posavec, K. (2004). Socijalna distanca prema nacionalnim ili etničkim i religijskim skupinama. Pedagogijska istraživanja, 1(1), 105-119. 
Prinstein, M.J. i Dodge, K.A. (2008). Peer influence processes among youth. New York: Guilford.

Rasmussen, M., Damsgaard, M.T., Holstein, B.E., Poulsen, L.H. i Due, P. (2005). School connectedness and daily smoking among boys and girls: The influence of parental smoking norms. European Journal of Public Health, 15(6), 607-612.

Šlezak, H. i Šakaja, L. (2012). Prostorni aspekti socijalne distance prema Romima. Hrvatski geografski glasnik, 74(1), 91-109.

Šućur, Z. (2000). Romi kao marginalna skupina. Društvena istraživanja, 2-3, 211-227.

Todisijevič, B. i Enyedi, Z. (2003). Authoritarianism vs. cultural pressure. Journal of Russian and East European Psychology, 40, 31-54.

Tomašić Humer, J. i Čorkalo Biruški, D. (2015). Provjera temeljnih postavki razvojnog modela subjektivne grupne dinamike na ad hoc grupama mladih. Društvena istraživanja, 3, 367-386.

Tredoux, C.G. i Dixon, J.A. (2009). Mapping the multiple contexts of racial isolation: The case of Long Street, Cape Town. Urban Studies, 46(4), 761-777.

Turalija, M. (2015). Stavovi prema Romima. (Neobjavljeni završni rad). Sveučilište u Osijeku, Filozofski fakultet, Osijek.

Turner, J.C., Hogg, M.A., Oakes, P.J., Reicher, S.D. i Wetherell, M.S. (1987). Rediscovering the social group: A self-categorization theory. Cambridge, MA, US: Basil Blackwell.

Wagner, U., Christ, O., Pettigrew, T.F., Stellmacher, J. i Wolf, C. (2006). Prejudice and minority proportion: Contact instead of threat effects. Social Psychology Quarterly, 69(4), 380-390.

Werner-Wilson, R.J. i Arbel, O. (2000). Assessment of interpersonal influences on adolescents: The parent and peer influence scale. The American Journal of Family Therapy, 28(3), 265-275.

Whitaker, D.J. i Miller, K.S. (2000). Parent-adolescent discussions about sex and condoms impact on peer influences of sexual risk behavior. Journal of Adolescent Research, 15(2), 251-273.

\title{
The Role of Parent and Peer Norms in Explaining Negative Outgroup Attitudes in Adolescence
}

\begin{abstract}
The aim of the research was to investigate the role of parent and peer norms in explaining outgroup attitudes in adolescence and to explore how this relation depends on the general susceptibility to parent or peer norms. The study was conducted on a sample of 457 high school students from Zagreb. We measured attitudes toward the Roma ethnic group, using the Modern Racism Scale, Social Distance Scale (self-assessment and estimation for parents and peers), Parent and Peer Pressure Scale and sociodemographics. Results indicate that, in average, participants show a high level of negative attitude toward Roma on a Social Distance Scale
\end{abstract}


(would agree on going to school with Roma peers, but wouldn't agree on being friends with or dating them), and a moderate level of negative attitude on the Modern Racism Scale. Both parent and peer norm have a significant contribution in explaining negative attitudes on a social distance measure (a more negative norm is associated with more negative attitudes), with parent norm having a larger contribution than peer norm. Regarding modern prejudice, there is only a significant contribution for parent (but not for peer norm). Hypothesis about the moderation effect of general susceptibility to parent or peer norms on the norm-prejudice relationship was not confirmed, which can be explained by method factors. Results of this research indicate a possible contribution of ingroup norms to development and maintenance of negative outgroup attitudes, yet further research, using stronger research designs is needed.

Keywords: parent norms, peer norms, prejudice, adolescence, parent and peer influence

\section{Papel de las normas de los padres y los coetáneos para explicar actitud intergrupal negativa en adolescencia}

\section{Resumen}

El objetivo de esta investigación fue examinar el papel de las normas de los padres y los coetáneos para explicar la actitud intergrupal negativa en adolescencia, tanto como verificar cómo esta relación depende de la tendencia general de someterse bajo la influencia de los padres y los coetáneos. En la investigación participaron 457 alumnos de secundaria de Zagreb. Se han investigado actitudes intergrupales negativas hacia el grupo étnico de los gitanos a través del cuestionario que constaba de la Escala de racismo moderno, Escala de distancia social (autoevaluación y evaluación para los padres y los coetáneos), Escala de influencia de los padres y los coetáneos y las cuestiones sociodemográficas. Los resultados han demostrado que los participantes en general muestran una actitud negativa muy marcada hacia el grupo étnico de los gitanos en la medida de la distancia social (aceptarían frecuentar la misma clase, pero no hacer amigos, ser parientes o pareja romántica), tanto como actitud moderadamente negativa en la medida de racismo moderno. Tanto la norma de los padres como la de los coetáneos contribuye significativamente a la explicación de la actitud negativa que tienen los participantes en la medida de distancia social (la norma más negativa está relacionada con la mayor distancia), en lo que en mayor grado influye la norma de los padres que la de los coetáneos. En cuanto a los prejuicios modernos, cuenta sólo la norma de los padres. La suposición sobre la susceptibilidad y su efecto moderador en la relación entre las normas de los padres y los coetáneos y la actitud no se ha confirmado, que se podría explicar con los factores metodológicos. Los resultados de esta investigación indican cierta influencia de las normas intragrupales en crear y mantener actitudes intergrupales negativas, pero hace falta realizar futuras investigaciones con esbozos metodológicos más estrictos.

Palabras clave: normas de los padres, normas de los coetáneos, prejuicios, adolescencia, influencia de los padres y los coetáneos

Primljeno: 22.11.2016. 